\title{
PENANGGULANGAN TINDAK PIDANA KORUPSI PADA APARATUR SIPIL NEGARA
}

\author{
Sigit Yuwono \\ Program Magister Ilmu Hukum \\ Pascasarjana Universitas Islam Malang \\ Email : sigityw@gmail.com
}

\begin{abstract}
Abstrak
Banyak faktor yang mendorong seseorang Aparatur Sipil Negara (ASN) individu untuk melakukan tindak tindak pidana korupsi yang salah satunya adalah latar belakang pendidikan dan status sosial . Diharapkan dengan semakin tinggi tingkat pendidikan maka tingkat korupsi dapat ditekan karena seseorang akan menyalurkan kemampuannya sesuai dengan skillnya. Selain itu juga tingkat mental dan penguasaan dari seorang individu. Selain itu juga upaya reformasi dan pencerahan kualitas mental dan moral manusia, sehingga diharapkan dengan adanya pencerahan ini seorang individu mempunyai pertahanan diri dan mental yang kuat untuk dapat menghindari melakukan korupsi.
\end{abstract}

Kata kunci: korupsi, akibat, penanggulangan, pegawai

\begin{abstract}
Many factors encourage a person of the State Civil Apparatus (ASN) individuals to commit acts of corruption, one of which is an educational background and social status. It is expected that the higher the level of education, the level of corruption can be suppressed because someone will channel their abilities according to their skills. In addition, the mental level and mastery of an individual. In addition, efforts to reform and enlighten human mental and moral qualities, so that it is expected that with this enlightenment an individual has a strong mental and self defense to be able to avoid corruption.
\end{abstract}

Keywords: corruption, effects, countermeasures, employees

\section{PENDAHULUAN}

Dalam kehidupan manusia disadari bahwa yang benar, yang indah dan yang baik itu menyenangkan, membahagiakan, menentramkan, dan memuaskan manusia. Sebaliknya yang salah, yang jelek, dan yang buruk itu menyengsarakan, menyusahkan, dan membosankan manusia. Berdasarkan dua sisi yang bertolak belakang ini, manusia adalah sumber penentu yang menimbang, menilai, memutuskan untuk memilih yang paling menguntungkan (nilai moral) atau merugikan banyak orang (dalam pendekatan norma yuridis), ${ }^{1}$ termasuk memilih melakukan kejahatan ataukah tidak.

Soerjono Soekanto mengutip pendapat pakar ilmu sosial dan humaniora A. Laccasagne yang berpendapat, bahwa yang terpenting adalah keadaan sosial lingkungan kita, karena lingkungan merupakan suatu wadah pembenihan untuk

\footnotetext{
${ }^{1}$ Abdulkadir Muhammad, Etika Profesi Hukum, (Bandung: Citra Adtya, Bandung, 1997),
} hal. 1-2. 


\section{$\mathcal{H}$ urnal Negara dan Keadilan \\ p-ISSN 2302-7010 e-ISSN 2721-9801}

kejahatan dan kuman adalah penjahatnya. Demikian pula G. Tarde menyatakan bahwa kejahatan bukanlah gejala antropologik, melainkan gejala sosiologik dimana semua perbuatan penting manusia dilakukan karena proses peniruan atau imitasi, dilakukan di bawah kekuasaan contoh sebagaimana kejadian-kejadian di dalam masyarakat yang lain. Karena itu R. Owen juga mengatakan, bahwa lingkungan yang tidak baik membuat kelakuan seseorang menjadi jahat. ${ }^{2}$

Kejahatan merupakan kata yang tidak asing dalam kehidupan suatu masyarakat. Ada sedikit perbuatan yang dinilai merugikan seperti menggangu dan merugikan sesama manusia sudah disebut sebagai tindak kejahatan. Masyarakat akhirnya gampang memberikan julukan pada seseorang yang sering berbuat keji, merugikan orang lain, dan melanggar norma-norma hukum negara dengan sebutan sebagai "orang jahat". 3

Dewasa ini tindak kejahatan semakin bermacam-macam dan punya kecenderungan meningkat secara kuantitatif dan kualitatif. Pelakunya (kejahatan) juga dari berbagai status. Ada yang menjadi pelaku kejahatan yang tingkat pendidikannya rendah, dan ada pula pelaku kejahatan yang berasal dari kalangan berpendidikan tinggi. Masing-masing pelaku ini mempunyai tujuan dalam melakukan kejahatan.

Terbukti bisa dibaca, bahwa kejahatan, diantarnay akorupsi di tengah masyarakat bisa berkembang atau tidak, adalah sejalan dengan kondisi masyarakat. Seseorang atau sekelompok orang bisa saja melakukan suatu kejahatan, yang perilakunya ini bisa disebabkan oleh alasan atau factor tertentu.

Tidak selalu sama factor yang menyebabkan terjadinya suatu kejahatan korupsi bagi seseorang aparatur sipil negara (ASN) tertentu dengan orang lainnya. Latarbelakang kehidupan atau keadaan bisa berbeda atau sama, tapi pilihan melakukan kejahatannya tidak selalu sama.

\section{METODE PENELITIAN}

Dalam riset ini, jenis penelitian ini adalah yuridis empiric, yang Menurut Ronny Hanitijo Soemitro, yuridis sosiologis artinya adalah mengidentifikasikan dan mengkonsepsikan hukum sebagai institusi sosial yang riil dan fungsional dalam sistem kehidupan yang mempola. ${ }^{4}$

Dengan pendekatan peraturan perundang-undangan dan studi kasus, teknik pengambilan bahan yang digunakan adalah teknik wawancara, dokumentasi, dan pengamatan, sumberdatanya dari informan di lapangan dan bahan hukumnya menggunakan bahan hukum primer dan sekunder. Sedangkan analisisnya menggunakan deskriptif kualitatif

\section{PEMBAHASAN}

Jika dibaca dari segi semantik, "korupsi" berasal dari bahasa Inggris, yaitu corrupt, yang berasal dari perpaduan dua kata dalam bahasa latin yaitu com yang berarti bersama-sama dan rumpere yang berarti pecah atau jebol. Istilah "korupsi" juga bisa disebut sebagai suatu perbuatan tidak jujur (unfair) atau penyelewengan atau penyalahgunaan (abuse) yang dilakukan karena adanya suatu pemberian.

2.

${ }^{2}$ Abdurrahman, Biarlah Kejahatan Memberi Tantangan, Makalah, (Surabaya, 2012), hal.

${ }^{3}$ Gusmian Mawas, Kejahatan dan Negara, (Jakarta: Pembaruan-Press, 2011), hal. 2.

${ }^{4}$ Ronny Hanitijo Soemitro, Pengantar Penelitian Hukum, (Jakarta, 1994), hal. 45. 


\section{Hurnal Negara dan $\mathcal{X}$ eadilan \\ p-ISSN 2302-7010 e-ISSN 2721-9801}

Dalam prakteknya, korupsi lebih dikenal sebagai menerima uang yang ada hubungannya dengan jabatan tanpa ada catatan administrasinya. ${ }^{5}$ Baharuddin Lopa mengutip pendapat dari David M. Chalmers, mendeskripsikan makna atau istilah korupsi dalam berbagai bidang, yakni yang menyangkut masalah penyuapan, yang berhubungan dengan manipulasi di bidang ekonomi, dan yang menyangkut bidang kepentingan umum. ${ }^{6}$

Dalam tulisan Andi Hamzah, (2005) juga disebut bahwa korupsi berawal dari bahasa latin corruptio atau corruptus. Corruptio berasal dari kata corrumpere, suatu kata latin yang lebih tua. Dari bahasa latin itulah turun ke banyak bahasa Eropa seperti Inggris yaitu corruption, corrupt; Prancis yaitu corruption; dan Belanda yaitu corruptie, korruptie. Dari Bahasa Belanda ini kemudian turun ke Bahasa Indonesia yaitu korupsi. ${ }^{7}$

Banyak ahli yang mencoba merumuskan korupsi, yang jika dilihat dari struktrur bahasa dan cara penyampaiannya yang berbeda, tetapi pada hakekatnya mempunyai makna yang sama. Kartono (1983) memberi batasan korupsi sebagi tingkah laku individu yang menggunakan wewenang dan jabatan guna mengeduk keuntungan pribadi, merugikan kepentingan umum dan negara. Jadi korupsi merupakan gejala salah pakai dan salah urus dari kekuasaan, demi keuntungan pribadi, salah urus terhadap sumber-sumber kekayaan negara dengan menggunakan wewenang dan kekuatan-kekuatan formal (misalnya denagan alasan hukum dan kekuatan senjata) untuk memperkaya diri sendiri.

Pakar yang banyak mengamati tentang dinamika peradaban, Samuel Huntington (1968) memberikan pengertian korupsi sebagai perilaku pejabat publik yang menyimpang dari norma-norma yang diterima oleh masyarakat, dan perilaku menyimpang ini ditujukan dalam rangka memenuhi kepentingan pribadi.

Korupsi juga dipahami sebagai tingkah laku individu yang menggunakan wewenang dan jabatan guna mengeduk keuntungan pribadi, merugikan kepentingan umum. Korupsi juga sering dimengerti sebagai penyalahgunaan kekuasaan dan kepercayaan untuk keuntungan pribadi. Namun korupsi juga bisa dimengerti sebagai perilaku tidak mematuhi prinsip "mempertahankan jarak". "Mempertahankan jarak" ini maksudnya adalah dalam mengambil sebuah keputusan, baik di bidang ekonomi, politik, dan sebagainya, permasalahan dan kepentingan pribadi atau keluarga tidak memainkan peran (Agus Suradika, 2009). Selain itu, korupsi juga dapat dikatakan sebagai representasi dari rendahnya akuntabilitas birokrasi publik. $^{8}$

Nye, J.S. (1967) dalam "Corruption and political development" mendefiniskan korupsi sebagai prilaku yang menyimpang dari aturan etis formal yang menyangkut tindakan seseorang dalam posisi otoritas publik yang disebabkan oleh motif pertimbangan pribadi, seperti kekayaan, kekuasaan dan status. ${ }^{9}$

Kamus Umum Bahasa Indonesia (W.J.S. Poerwadarminta) adalah sebagai perbuatan curang, dapat disuap, dan tidk bermoral. adapun menurut Kamus Besar

${ }^{5}$ Alfan Hasib, Korupsi dari Masa Ke Masa, (Surakarta: Lalunggung Media, 2012), hal.

2.

${ }^{6}$ Evi Hartanti, Tindak Pidana Korupsi. (Jakarta: Sinar Grafika, 2005), hal. 9.

${ }^{7}$ Gusmiaan Mawas, Op.Cit, hal. 3.

${ }^{8}$ Himawan Sukotjo, Koruptor Tanpa Tanding, (Jakarta: EM-Pres, 2011), hal. 2.

${ }^{9} \mathrm{Ibid}$, hal.2-3. 


\section{$\mathcal{H}$ urnal Negara dan Keadilan \\ p-ISSN 2302-7010 e-ISSN 2721-9801}

Bahasa Indonesia, korupsi adalah penyelewengan atau penggelapan uang negara atau perusahaan dan sebagainya untuk kepentingan pribadi maupun orang lain.sedangkan di dunia internasional pengertian korupsi berdasarkan Black Law Dictionary yang mempunyai arti bahwa suatu perbuatan yan dilakukan dengan sebuah maksud untuk mendapatkan beberapa keuntungan yang bertentangan dengan tugas resmi dan kebenaran-kebenaran lainnya "sesuatu perbuatan dari suatu yang resmi atau kepercayaan seseorang yang mana dengan melanggar hukum dan penuh kesalahan memakai sejumlah keuntungan untuk dirinya sendiri atau orang lain yang bertentangan dengan tugas dan kebenaran-kebenaran lainnya. ${ }^{10}$ Korupsi merupakan tindak kejahatan serius, sehingga siapapun yang melakukannya tergolong penjahat"istimewa" dari segi cara, pola dan akibatakibatnya. $^{11}$

Korupsi merupakan masalah besar bagi Negara kita apabila tidak ditangani secara serius, karena hal ini berdampak pada kehidupan sosial dan ekonomi Negara kita. Untuk itu pihak berwenang harus disiplin dalam menegakkan kebenaran terutama dalam hal korupsi. Selain itu juga dari faktor individunya harus diberikan pengarahan tentang pendidikan korupsi sehingga mentalnya akan terbentuk dengan baik tanpa adanya korupsi. Faktor lainnya adalah faktor birokrasi sebagai organisasi publik penyelenggara pemerintahan dan pelayanan publik sehari-hari. Birokrasi sebagai salah satu ciri dari masyarakat modern tidak dapat dielakkan lagi pasti muncul dalam proses pembangunan.

Permasalahan korupsi berkaitan dengan segi-segi moral, sifat, jabatan dalam instansi atau aparatur pemerintah, penyelewengan kekuasaan dalam jabatan karena pemberian, faktor ekonomi dan politik, serta penempatan keluarga atau golongan kedalam kedinasan di bawah kekuasaan jabatannya. Untuk itu penegak hukum harus mempunyai kemampuan untuk melihat secara jauh permasalahan yang terjadi berkaitan dengan adanya korupsi ini.

Pembangunan Nasional berdasarkan Pancasila dan Undang-Undang Dasar 1945 bertujuan untuk mewujudkan Indonesia adil, makmur dan sejahtera. Untuk itu perlu secara terus menerus ditingkatkan usaha pencegahan dan pemberantasan tindak pidana korupsi yang semakin meluas dan meningkat dalam kuantitas dan kualitas. Hal ini menujukkan bahwa korupsi merupakan tindak kejahatan yang mempunyai dampak sangat besar terhadap kehidupan masyarakat baik dari segi ekonomi maupun sosial. Korupsi mengakibatkan sebagian besar rakyat Indonesia menderita dan hidup dalam kemiskinan, penanggulangan korupsi menjadi problem bersama mengingat korupsi berkembang begitu pesat bagaikan jamur hingga merambah ke instansi terbawah sekalipun. KOrupsi ini cermin pelanggaran hukum yang serius yang dilakukan oleh ASN. Menurut E.Utrecht hukum itu adalah himpunan peraturan-peraturan (perintah-perintah dan laranganlarangan) yang mengurus tata tertib suatu masyarakat dan karena itu harus ditaati oleh masyarakat itu. ${ }^{12}$

Salah satu faktor untuk mengukur adanya perilaku korupsi yang dilakukan oleh pejabat publik dan politisi maka digunakanlah indeks persepsi korupsi (IPK). Sebagai conotoh, berdasarkan IPK pada tahun 2007 yang diluncurkan oleh

${ }^{10}$ Alfan Hasib, Op.Cit, hal. 3-4.

${ }^{11}$ Gusmian Mawas, Op.Cit, hal. 2.

${ }^{12}$ CST. Kansil, Pengantar Ilmu Hukum dan Tata Hukum Indonesia, (Jakarta: Sinar Grafika, 2000), hal. 9 


\section{Zurnal Negara dan $\mathcal{X}$ eadilan \\ p-ISSN 2302-7010 e-ISSN 2721-9801}

Transparancy Internasional menujukkan bahwa Indonesia berada diurutan 142 dengan nilai 2.3. Dengan nilai ini Indonesia termasuk negara terkorup di dunia bersama-sama 71 negara lainnya yang nilai skornya kurang dari 3.Hal; ini akan berdampak pada pandangan Negara lain terhadap Indonesia yang akan membawa multiplier efek dari segala aspek (Chrisna Suhendi dan Zaenuddin, 2015).

Banyaknya permasalahan kasus korupsi di wilayah hukum Polres Pasuruan, memerlukan penanganan secara khusus agar dapat terselesaikan dengan baik. Salah satu kasus korupsi yang perlu segera ditangani di Wilayah hukum Polres Pasuruan adalah pemerasan yang dilakukan oleh Aparatur Sipil Negara, dimana hal ini akan membawa dampak yang kurang baik bagi jajaran Pemerintahan di Kab. Pasuruan. Selain itu melanggar ketentuan dalam Pasal 12 huruf e UU No 20 tahun 2001 tentang pemberantasan tindak pidana korupsi.

Permasalahan korupsi dii Pasuruan berkaitan dengan segi-segi moral, sifat, jabatan dalam instansi atau aparatur pemerintah, penyelewengan kekuasaan dalam jabatan karena pemberian, Untuk itu perlu secara terus menerus ditingkatkan usaha pencegahan dan pemberantasan tindak pidana korupsi yang semakin meluas dan meningkat. Banyaknya permasalahan kasus korupsi di wilayah hukum Polres Pasuruan, memerlukan penanganan secara khusus agar dapat terselesaikan dengan baik. Salah satu kasus korupsi yang perlu segera ditangani di Wilayah hukum Polres Pasuruan adalah penggelapan dana Simpan Pinjam Perempuan (SPP) dan Dana Operasional Kegiatan (DOK), dimana hal ini akan membawa dampak yang kurang baik bagi jajaran Pemerintahan di Kab. Pasuruan. Selain itu melanggar ketentuan dalam Pasal 12 huruf e UU No 20 tahun 2001 tentang pemberantasan tindak pidana korupsi.

\section{KESIMPULAN}

Kasus tindak tindak pidana korupsi yang melibatkan ASN mengandung banyak aspek. Banyak faktor yang mendorong seseorang ASN individu untuk melakukan tindak tindak pidana korupsi yang salah satunya adalah latar belakang pendidikan dan status sosial. Diharapkan dengan semakin tinggi tingkat pendidikan maka tingkat korupsi dapat ditekan karena seseorang akan menyalurkan kemampuannya sesuai dengan skillnya. Selain itu juga tingkat mental dan penguasaan dari seorang individu.

Selain itu juga upaya reformasi dan pencerahan kualitas mental dan moral manusia atau ASN, sehingga diharapkan dengan adanya pencerahan ini seorang individu mempunyai pertahanan diri dan mental yang kuat untuk dapat menghindari melakukan korupsi. Hal inilah yang penting untuk setidaknya mencegah tindak pidana korupsi terjadi atau meluas.

\section{DAFTAR PUSTAKA}

Abdulkadir Muhammad, 1997, Etika Profesi Hukum, Bandung: Citra Adtya/ Abdurrahman, Biarlah Kejahatan Memberi Tantangan, Makalah, Surabaya, 2012. Alfan Hasib, 2012, Korupsi dari Masa Ke Masa, Surakarta: Lalunggung Media.

CST. Kansil, 2000, Pengantar Ilmu Hukum dan Tata Hukum Indonesia, Jakarta: Sinar Grafika.

Evi Hartanti, 2005, Tindak Pidana Korupsi. Jakarta: Sinar Grafika

Gusmian Mawas, 2011, Kejahatan dan Negara, Jakarta: Pembaruan-Press, Jakarta. 
Himawan Sukotjo, 2011, Koruptor Tanpa Tanding, Jakarta: EM-Pres.

Ronny Hanitijo Soemitro, 1994, Pengantar Penelitian Hukum, Jakarta. 